\title{
Implementasi Reformasi Birokrasi Bidang Perizinan Pananaman Modal di Kabupaten Kuningan*
}

\author{
Haris Budiman \& Suwari Akhmaddhian \\ Fakultas Hukum Universitas Kuningan \\ E-mail : harisbudiman9@yahoo.co.id
}

\begin{abstract}
A b s t r a c t
Bureaucratic reform is essentially an attempt to reform and fundamental changes to the systems of governance in order to reach the goal of bureaucratic reform to accelerate achievement of good governance and efforts to improve support for local government in Increasing performance. Bureaucracy reform program running which consisted principally of institutional reform, human resources management reform and information technology support in the licensing process. Institutional reform is to establish a new agency that handles the licensing process in the past, integrated licensing process to go through the different agencies and with the reform of the bureaucracy in the licensing process united in one body that is unified, improve human resources through training and increase the transparency of information through the management information technology support. Bureaucratic reform in investment licensing and the area is already under way in an effort to improve service to the community that good governance is not just adream and soon became a reality. Keywords: Licensing, Service, Bureaucratic Reform.
\end{abstract}

\section{A b s trak}

Reformasi birokrasi pada hakikatnya merupakan upaya untuk melakukan pembaharuan dan perubahan mendasar terhadap sistem penyelenggaraan pemerintahaan sehingga tercapai tujuan reformasi birokrasi yaitu untuk memepercepat tercapainya tata kelola pemerintahan yang baik dan upaya memperbaiki dukungan terhadap pemerintah daerah dalam meningkatakan kinerjanya. Program reformasi birokrasi berjalan yang pada pokoknya terdiri dari reformasi kelembagaan, sumber daya manusia dan reformasi manajemen dukungan teknologi informasi dalam proses perizinan. Reformasi kelembagaan yaitu dengan membentuk lembaga baru yang menangani proses perizinan terpadu yang dimasa lalu proses perizinan harus melalui instansi yang berbeda dan dengan adanya reformasi birokrasi proses perizinan di satukan dalam satu badan yang bersifat terpadu, meningkatkan sumberdaya manusia melalui diklat dan meningkatkan keterbukaan informasi melalui manajemen dengan dukungan teknologi informasi. Reformasi birokrasi perizinan penanaman modal di daerah sudah dan sedang berjalan dalam upaya meningkatkan pelayanan terhadap masyarakat sehingga tata kelola pemerintahan yang baik bukan hanya sekedar impian dan segera menjadi kenyataan. Kata kunci : Perizinan, Pelayanan, Reformasi Birokrasi.

\footnotetext{
- Artikel ini merupakan hasil Hibah Penelitian Dosen Pemula Dikti 2013, Sumber dana dari Dikti dengan No.282/SP2H/PL/DIT.LITABMAS/V/2013 tanggal 27 Juni 2013
} 


\section{Pendahuluan}

Pembangunan ekonomi menjadi salah satu jalan dalam mensejahterakan masyarakat, dalam pembangunan ekonomi di perlukan birokrasi yang ramah terhadap penanaman modal. Dalam pembangunan ekonomi terkait erat dengan bergeraknya sektor ekonomi yang menciptakan lapangan kerja bagi masyarakat sehingga tujuan Negara dalam memakmurkan rakyatnya tercapai. Penanman Modal yang ada baik yang berasal dari dalam negeri maupun luar negeri mengharapkan proses perizinan penanaman modal yang mereka lakukan berjalan dengan cepat dan murah. Reformasi birokrasi disuarakan mengingat pada masa Orde Baru, birokrasi dijadikan lahan subur untuk praktik kolusi, korupsi, dan nepotisme (KKN). Ketika itu, pemerintahan Orde Baru ditopang oleh birokrasi yang rapuh, tidak profesional, dan lebih mengutamakan kepentingan segelintir elite, pengusaha, dan kroni. Soal pelayanan publik atau kepentingan publik, itu nomor sekian. Praktik birokrasi yang korup, inefisien, dan tidak transparan masih sangat terasa hingga saat ini sehingga dampak negatif dari birokrasi model lama masih menghantui dunia usaha. Banyak pihak, terutama kalangan penyelenggaranegara, yang tidak menyadari, bahkan mungkin sengaja, memelihara birokrasi yang bisa dimanfaatkan untuk kepentingan sedikit orang. Ukuran keberhasilan reformasi birokrasi adalah jika manfaatnya dirasakan langsung masyarakat sehingga kenyamanan dirasakan. Misalnya saja, jika masyarakat ingin mengurus perizinan masih merasa dipersulit maka reformasi belum berjalan.Untuk mewujudkan keberhasilan reformasi birokrasi, sebenarnya tidak hanya dari kalangan birokrasi, tetapi juga harus dari luar. Publik harus terus menerus memberikan kritik membangun, menyampaikan aspirasinya, dan berpartisipasi. Dengan adanya reformasi birokrasi diharapkan menjadi tatanan dalam kehidupan masyarakat sehingga dengan adanya tatanan dalam kehidupan masyarakat menjadi serba teratur sehingga tercipta nilai dasar dalam masyarakat yaitu tentang keadilan, kepastian hukum dan kemanfaatan sosial ${ }^{2}$. Pelayanan publik yang berkualitas menjadi salah satu tolok ukur untuk melihat apakah disuatu organisasi pemerintah (sektor

2 Asri M Saleh, Vol.3 No.2 Tahun 2004, Arti Penting Kehadiran Ombudsman Bagi Masyarakat Di Provinsi Riau, Jurnal Hukum Respublica, hlm.228-237 
publik) telah terjadi reformasi birokrasi. Masifnya kesan miring yang muncul atas pelayanan publik yang dilakukan oleh sektor publik, tidak terlepas dari kenyataan bahwa rendahnya kualitas pelayanan publik yang diberikan kepada masyarakat sebagai konsumen. Rendahnya pelayanan publik dimaksud, antara lain ditandai dengan : pertama, tidak transparannya biaya dalam pengurusan perizinan. Kedua, berbelit-belitnya pelayanan bahkan tidak jarang membuat masyarakat menjadi frustasi. Ketiga, waktu pelayanan yang tidak jelas, sehingga masyarakat tidak dapat memprediksi kapan selesainya.

Menurut Davidow (dalam Lovelock, 1988) pelayanan adalah : "Service is those thing which when added to a product increase its utility or value to the customer". Pelayanan sendiri adalah hal-hal yang jika diterapkan terhadap suatu produk akan meningkatkain daya atau nilai terhadap pelanggan. Lebih jauh Lovelock berpendapat bahwa pelayanan yang baik membutuhkan instruktur pelayanan yang sangat baik pula. Hal ini bahwa yang paling penting adalah membuat setiap orang dalam organisasi berkualitas. Kualitas pelayanan sendiri menurut Crosby, Lehtimen, dan Wyckoff (dalam Lovelock, 1988) merupakan penyesuaian terhadap perincianperincian (conformance of specification), dimana kualitas ini dipandang sebagai derajat keunggulan yang ingin dicapai, dilakukannya kontrol terus menerus dalam mencapai keunggulan tersebut dalam rangka memenuhi kebutuhan pengguna jasa ${ }^{3}$. Diharapkan dengan adanya reformasi birokrasi di sektor perizinan penanaman modal berjalan dengan baik sehingga masyarakat yang mengajukan perizinan mendapatkan kemudahan dan secara tidak langsung membantu Negara dalam menciptakan masyarakat yang sejahtera karena mempunyai pekerjaan dan dapat menghidupi keluarganya dengan layak. Pembangunan ekonomi diperlukan dalam upaya mensejahterakan masyarakat melalui penciptaan proyek-proyek baru sehingga menyerap lapangan kerja dan petumbuhan ekonomi.

Ukuran keberhasilan reformasi birokrasi adalah jika manfaatnya dirasakan langsung masyarakat sehingga kenyamanan dirasakan. Misalnya saja, jika masyarakat

\footnotetext{
${ }^{3}$ Riyadi Soeprapto, No. 2 Agustus 2005, Pengembangan Model Citizen Charter Dalam Meningkatkan Pelayanan Publik Di Indonesia, Delegasi, hlm. 123-150
} 
ingin mengurus perizinan masih merasa dipersulit maka reformasi belum berjalan.Untuk mewujudkan keberhasilan reformasi birokrasi, sebenarnya tidak hanya dari kalangan birokrasi, tetapi juga harus dari luar. Publik harus terus menerus memberikan kritik membangun, menyampaikan aspirasinya, dan berpartisipasi. Dengan adanya reformasi birokrasi diharapkan menjadi tatanan dalam kehidupan masyarakat sehingga dengan adanya tatanan dalam kehidupan masyarakat menjadi tertib ${ }^{4}$. Pelayanan yang berkualitas adalah pelayanan yang cepat, menyenangkan, tidak mengandung kesalahan serta mengikuti proses dan prosedur yang telah ditetapkan, karenanya pelayanan yang berkualitas ditentukan oleh pihak yang ingin dilayani dan pihak yang ingin dipuaskan kebutuhannya. ${ }^{5}$ Untuk mengukur kualitas pelayanan publik dipergunakan standar pelayanan .Albert dan Zemke (dalam Fathir Fajar Sidiq), menyebut kualitas pelayanan publik dipengaruhi oleh banyak faktor yakni interaksi dari sistem pelayanan, sumber daya manusia pemberi pelayanan, strategi dan pelanggan. ${ }^{6}$ Pemerintah Kota dan Kabupaten secara intens mengindentifikasi hambatan-hambatan dalam melakukan implementasi reformasi birokrasi di bidang pelayanan publik. Beberapa daerah berupaya melakukan reformasi birokrasi perizinan dengan adanya pelaksanaan bantuan teknis pembentukan Instansi Perizinan Terpadu Satu Pintu (PTSP) contohnya di Pemerintah Kabupaten Timor Tengah Utara. Acara penandatanganan ini dibarengi dengan seminar sosialisasi tentang Prakarsa Reformasi Birokrasi Perizinan dan dihadiri oleh segenap jajaran Pemerintah Kabupaten Timor Tengah Utara, Sektor swasta dan pelaku usaha, Lembaga Swadaya Masyarakat dan undangan lainnya. Proses mendapatkan ijin usaha serta dokumen dokumen lain yang selama ini sering dipersepsikan berbelit belit, lama, dan mahal ini akan perlahan diubah seiring dengan berdirinya Layanan Perizinan terpadu atau PTSP kelak menjadi mudah, murah dan

\footnotetext{
${ }^{4}$ Satjipto Rahardjo, Ilmu Hukum, cet.2006, (Bandung::PT.Citra Aditya Bhakti,1982), halaman.13

${ }^{5}$ Yogi S dan Ikhsan, Standar Pelayanan Publik Di Daerah, ( Jakarta : Hand Book Manajemen Pemerintahan Daerah, LAN, 2006), halaman 12

${ }^{6}$ Fathir Fajar Sidiq, Kasus Gizi Buruk dan Wajah Pelayanan Publik di Kota Depok", www.radardepok.com, , Diakses tanggal 24 Desember 2012
} 
cepat. ${ }^{7}$ Diharapkan dengan adanya reformasi birokrasi di sektor perizinan penanaman modal berjalan dengan baik sehingga masyarakat yang mengajukan perizinan mendapatkan kemudahan dan secara tidak langsung membantu Negara dalam menciptakan masyarakat yang sejahtera karena mempunyai pekerjaan dan dapat menghidupi keluarganya dengan layak. Pembangunan ekonomi diperlukan dalam upaya mensejahterakan masyarakat melalui penciptaan proyek-proyek baru sehingga menyerap lapangan kerja dan petumbuhan ekonomi.

\section{Perumusan Masalah}

Adapun yang menjadi pokok permasalahan yang akan menjadi fokus perhatian utama yang akan dibahas dalam penelitian ini dapat di uraikan dalam pertanyaan diantaranya sebagai berikut:

1. Bagaimana implementasi reformasi birokrasi di sektor perizinan penanaman modal di Kabupaten Kuningan.?

2. Apakah manfaat reformasi birokrasi di sektor perizinan penanaman modal bagi pelayanan publik di bidang perizinan usaha di Kabupaten Kuningan.?

\section{Metode Penelitian}

Metode penelitian yang digunakan oleh penyusun dalam pembahasan penelitian ini adalah metode evaluatif analisis, yaitu suatu metode mengumpulkan dan menyajikan data yang diperoleh untuk menganalisis keadaan yang sebenarnya dan selanjutnya dilakukan analisa rasional berdasarkan acuan yuridis melalui penelitian kepustakaan dan penelitian lapangan. Metode penelitian hukum, menurut Soerjono Soekanto adalah " suatu kegiatan ilmiah, yang di dasarkan pada metode, sistematika dan pemikiran tertentu, yang bertujuan mempelajari satu atau beberapa gejala hukum tertentu, dengan menganalisanya. ${ }^{8}$

\footnotetext{
${ }^{7}$ www.tribuntimur.com, Perizinan Satu Atap di Kabupaten timor Tengah Utara", Diakes tanggal 04 Desember 2012

${ }^{8}$ Soerjono Soekanto, Pengantar Penelitian Hukum.cet.2007, ( Jakarta : UI Press, 1984), hlm.5
} 


\section{Data dan Sumbernya}

a. Data primer atau data empiris yaitu sumber data dari melakukan observasi dan data berupa keterangan-keterangan dari nara sumber, antara lain pengusaha, pengurus Apindo, masyarakat, akademisi dan praktisi hukum.

b. Data sekunder yang digunakan dalam penelitian ini, Penggunaan data sekunder ini karena memiliki beberapa keuntungan, yaitu ${ }^{9}$ :

1) Pada umumnya data sekunder dalam keadaan siap terbuat dan dapat dipergunakan dengan segera.

2) Baik bentuk maupun isi data sekunder, telah di bentuk dan disini oleh peneliti-peneliti terdahulu, sehigga peneliti kemudian, tidak mempunyai pengawasan terhadap pengumpulan, pengolahan, analisa, maupun konstruksi data.

3) Tidak terbatas oleh waktu maupun tempat.

Data sekunder, biasanya dibedakan menjadi tiga kategori, yaitu bahan hukum primer, bahan hukum sekunder dan bahan hukum tersier.

1) Bahan hukum primer, yaitu berupa ketentuan perundang-undangan yang mengikat. Adapun bahan hukum primer dalam penyusunan penelitian ini adalah :Undang Undamg Dasar Tahun 1945, Undang-Undang No.25 Tahun 2007 tentang Penanaman Modal, Undang-Undang No. 25 Tahun 2009 tentang Pelayanan Publik, Peraturan Menteri dalam Negeri Nomor 20 Tahun 2008 tentang Pedoman Organisasi dan Tata Kerja Unit Pelayanan Terpadu, Peraturan Menteri Dalam Negeri No.24 Tahun 2006 tentang Pedoman Penyelenggaraan Pelayanan Terpadu Satu Atap.

2) Bahan hukum sekunder, yaitu bahan-bahan yang menjelaskan bahan hukum primer, seperti hasil-hasil penelitian, teori, konsep pemikiran para ahli atau buku-buku yang berkorelasi dengan masalah yang di teliti. Dalam penyusunan penelitian ini, bahan hukum sekundernya, adalah buku-buku yang berkaitan langsung dengan masalah yang dikaji ,pendapat

\footnotetext{
${ }^{9}$ Op.Cit, hlm.12.
} 
para ahli, teori-teori yang terkait dengan masalah yang diteliti, serta putusan-putusan pengadilan tentang kasus yang telah terjadi dalam masyarakat. Yaitu : Yogi S dan Ikhsan, Standar Pelayanan Publik Di Daerah, Hand Book Manajemen Pemerintahan Daerah, LAN, 2006, Tim penyusun Ombudsprudensi Indonesia, Ombudsprudensi. Jakarta. Ombudsman Republik Indonesia: 2009

3) Bahan hukum tersier, yaitu bahan yang menjelaskan bahan hukum primer dan sekunder sepertinya kamus hukum. Yaitu : Badudu, J.S \& Sutan Muhammad Zain, Kamus Umum Bahasa Indonesia, Jakarta : Penerbit Pustaka Sinar Harapan, 1994.

\section{Tinjauan Pustaka}

Suatu penelitian membutuhkan kerangka berpikir untuk menjawab permasalahan-permasalahan yang telah di rumuskan. Kerangka berfikir yang dikenal dalam penelitian hukum terdiri dari atas kerangka teoritis dan kerangka konseptual. 'kerangka teoritis merupakan kerangka dimana masalah di ambil atau di hubungkan ${ }^{10}$. Pada umumnya kerangka teoritis disajikan dalam bentuk proposisi atau pernyataan yang salung berkaitan dan bertujuan memberikan gambaran yang sistematis tentang suatu gejala dan selanjutnya dapat membantu kasusu-kasus konkrit yang lebih adil, teori dalam penelitian mempunyai fungsi untuk mengarahkan kepada peneliti apa yang harus dilakukan.

Kerangka konseptual adalah kerangka yang lebih menggambarkan hubungan antara konsep-konsep khusus yang melandasi penelitian. Kerangka konseptual lebih mengedapankan definisi-definisi dari suatu permasalahan dengan kata lain konsep merupakan urian-uraian mengenai hubunganhubungan dalam fakta tersebut ${ }^{11}$.

\footnotetext{
${ }^{10}$ Soerjono Soekanto, Ringkasan metode Penelitian Hukum Empiris, (Jakarta:Ind-Hill 1990), hlm 110.

${ }^{11}$ Soerjono Soekanto, Pengantar Penelitian Hukum.cet.2007, ( Jakarta : UI Press, 1984), hlm.132.
} 
Pelayanan publik adalah kegiatan atau rangkaian kegiatan dalam rangka pemenuhankebutuhan pelayanan sesuai dengan peraturan perundangundangan bagi setiapwarga negara dan penduduk atas barang, jasa, dan/atau pelayanan administratif yang disediakan oleh penyelenggara pelayanan publik. Penyelenggara pelayanan publik yang selanj utnya disebut Penyelenggara adalah setiap institusi penyelenggara negara, korporasi, lembaga independen yang dibentuk berdasarkan undangundang untuk kegiatan pelayanan publik, dan badan hukum lain yang dibentuk semata-mata untuk kegiatan pelayanan publik. Atasan satuan kerja penyelenggara adalah pimpinan satuan kerja yang membawahi secara langsung satu atau lebih satuan kerja yang melaksanakan pelayanan publik.

Penyelenggaraan Pelayanan Terpadu Satu Pintu (PTSP) di bidang Penanaman Modal berdasarkan asas: kepastian hukum; keterbukaan; akuntabilitas; perlakuan yang sama dan tidak membedakan asal negara; efisiensi berkeadilan. Pelayanan Terpadu Satu Pintu (PTSP) dibidang Penanaman Modal bertujuan untuk membangun Penanaman Modaldalam memperoleh kemudahan pelayanan, fasilitas, dan informasi mengenaiPenanaman Modal, dengan cara mempercepat, menyederhanakan pelayanan, dan meringankan atau menghilangkan biaya pengurusan Perizinan dan Non-perizinan.

Secara umum terdapat beberapa prinsip-prinsip dasar dari Tata kelola Pemerintahan yang baik sehingga dapat menjadi tolak ukur untuk mengukur kinerja pemerintahan, baik buruknya pemerintahan dapat dinilai. Prinsip-prinsip Tata kelola Pemerintahan yang baik yaitu: (1) Partisipasi Masyarakat adalah semua masyarakat mempunyai suara dalam mengambil keputusan, baik secara langsung maupun tidak langsung yaitu melalui lembaga-lembaga perwakilan yang sah yang mewakili kepentingan mereka. Partisipasi menyeluruh tersbut dibangun berdasarkan kebebasan berkumpul dan mengungkapkan pendapat, secara kapasitas untuk berpartisipasi secara konstuktif; (2) Tegaknya Supermasi Hukum adalah kerangka hukum harus adil dan diberlakukan tanpa pandang bulu, termasuk di dalamnya hukum-hukum yang menyangkut hak asasi manusia; (3) Tranparansi adalah dibangun berdasarkan arus informasi yang bebas. Seluruh proses pemerintahan, lembaga-lembaga dan iinformasi 
perlu dapat diakses oleh pihak-pihak yang berkepentingan, dan informasi yang tersedia harus memadai agar dapat dimengerti dan dipantau.; (4) Peduli pada Stakeholder yaitu lembaga-lembaga dan seluruh proses pemerintahan harus berusaha melayani semua pihak yang berkepentingan; (5) Beroreintasi pada Konsensus tata kelola pemerintahan yang baik, menjembatani kepentingan-kepentingan yang berbeda demi terbangunnya suatu konsensus menyeluruh dalam hal apa yang terbaik bagi kelompok-kelompok masyarakat, dan bila mungkin konsensus dalam hal kebijakankebijakan dan prosedur-prosedur; (6) Kesetaraan yaitu semua warga masyarakat mempunyai kesempatan memperbaiki atau mempertahan kan kesejahtaraan merka; (7) Efektifitas dan Efisensi yaitu proses-proses pemerintahan dan lembaga-lembaga membuahkan hasil sesuai kebutuhan warga masyarakat dan menggunakan sumbersumber daya yang ada seoptimal mungkin; (8) Akuntabilitas adalah para pengambil keputusan bertanggung jawab baik kepada masyarakat maupun kepada lembagalembaga yang berkepentingan bentuk pertangung jawabanya sesuai dengan jenis dan tujuan organisasi yang bersangkutan; (9) Visi Strategis yaitu para pemimpin memiliki prespektif yang luas dan jauh ke depan atas pemerintahan yang baik dan pemnagunan manusia, serta kepekaan akan apa saja yang dibutuhkan untuk mewujudkan perkembangan tersebut ${ }^{12}$. Selain itu mereka juga harus memiliki pemahaman atas kompleksitas kesejarahan, budaya dan social yang menjadi dasar dalam prespektif itu.. Dalam proses kegiatan perizinan investasi, instansi atau badan harus mempunyai pertanggungjawaban melalui kewenangan pejabat-pejabat dalam menjalankan prosedur yang benar sesuai dengan peraturan. ${ }^{13}$

Organisasi penyelenggara pelayanan publik yang selanjutnya disebut Organisasi Penyelenggara adalah satuan kerja penyelenggara pelayanan publik yang berada di lingkungan institusi penyelenggara negara, korporasi, lembaga independen yang dibentuk berdasarkan undang-undang untuk kegiatan pelayanan publik, dan badan hukum lain yang dibentuk semata-mata untuk kegiatan pelayanan publik. Pelaksana pelayanan publik yang selanjutnya disebut Pelaksana adalah pejabat,

12 www.transparansi.or.id, Tata Kelola Pemerintahan Yang Baik, Diakses tanggal 04 Desember 2012

13 O.C.Kaligis, Dasar Hukum Mengadili Kebijakan Publik, (Jakarta : PT. Alumni, 2007), hlm.101-104. 
pegawai, petugas, dan setiap orang yang bekerja di dalam organisasi penyelenggara yang bertugas melaksanakan tindakan atau serangkaian tindakan pelayanan publik. Masyarakat adalah seluruh pihak, baik warga negara maupun penduduk sebagai orang perseorangan, kelompok, maupun badan hukum yang berkedudukan sebagai penerima manfaat pelayanan publik, baik secara langsung maupun tidak langsung. Standar pelayanan adalah tolok ukur yang dipergunakan sebagai pedoman penyelenggaraan pelayanan dan acuan penilaian kualitas pelayanan sebagai kewajiban dan janji penyelenggara kepada masyarakat dalam rangka pelayanan yang berkualitas, cepat, mudah, terjangkau, dan terukur. Reformasi birokrasi pada pelayanan publik mutlak harus berjalan karena reformasi birokrasi pintu masuk menuju pemerintahan baik yang sehat dan berkeadilan. ${ }^{14}$

Maklumat pelayanan adalah pernyataan tertulis yang berisi keseluruhan rincian kewajiban dan janji yang terdapat dalam standar pelayanan. Sistem informasi pelayanan publik yang selanjutnya disebut Sistem Informasi adalah rangkaian kegiatan yang meliputi penyimpanan dan pengelolaan informasi serta mekanisme penyampaian informasi dari penyelenggara kepada masyarakat dan sebaliknya dalam bentuk lisan, tulisan Latin, tulisan dalam huruf Braile, bahasa gambar, dan/atau bahasa lokal, serta disajikan secara manual ataupun elektronik. Mediasi adalah penyelesaian sengketa pelayanan publik antarpara pihak melalui bantuan, baik oleh ombudsman sendiri maupun melalui mediator yang dibentuk oleh ombudsman. Ajudikasi adalah proses penyelesaian sengketa pelayanan publik antar para pihak yang diputus oleh ombudsman.

Ombudsman adalah lembaga negara yang mempunyai kewenangan mengawasi penyelenggaraan pelayanan publik, baik yang diselenggarakan oleh penyelenggara negara dan pemerintahan termasuk yang diselenggarakan oleh badan usaha milik negara, badan usaha milik daerah, dan badan hukum milik negara serta badan swasta, maupun perseorangan yang diberi tugas menyelenggarakan pelayanan publik tertentu yang sebagian atau seluruh dananya bersumber dari anggaran pendapatan dan belanja Negara dan/atau anggaran pendapatan dan belanja daerah. Masyarakat memiliki hak

\footnotetext{
${ }^{14}$ Bintoro Tjokroamidjoyo, Reformasi Administrasi Publik, (Jakarta: MIA-Unkris Press, 2001).hlm.38.
} 
untuk melakukan pengawasan karena penyelenggaraan pemerintahan dan penyelenggaraan Negara adalah mandate yang di berikan rakyat melalui pemilihan umum sehingga rakyat dapat memperoleh pelayanan publik yang baik ${ }^{15}$..

Dalam Undang-undang No. 25 Tahun 2009 tentang Pelayanan Publik dimaksudkan untuk memberikan kepastian hukum dalam hubungan antara masyarakat dan Penyelenggara dalam pelayanan publik. Yang mempunyai tujuan yaitu : terwujudnya batasan dan hubungan yang jelas tentang hak, tanggung jawab, kewajiban, dan kewenangan seluruh pihak yang terkait dengan penyelenggaran pelayanan publik; terwujudnya sistem penyelenggaraan pelayanan publik yang layak sesuai dengan asas-asas umum pemerintahan dan korporasi yang baik; Terpenuhinya penyelenggaraan pelayanan public sesuai dengan peraturan perundangundangan; dan Terwujudnya perlindungan dan kepastian hukum bagi masyarakat dalam penyelenggaraan pelayanan publik. Dalam Undang-undang No. 25 Tahun 2009 tentang Pelayanan Publik Pasal 4 menyatakan bahwa Penyelenggaraan pelayanan publik berasaskan yaitu: kepentingan umum; kepastian hukum; kesamaan hak;keseimbangan hak dan kewajiban; keprofesionalan;. partisipatif;. persamaan perlakuan/tidak diskriminatif;. keterbukaan;. akuntabilitas;. fasilitas dan perlakuan khusus bagi kelompok rentan;. ketepatan waktu; dan. kecepatan, kemudahan, dan keterjangkauan.

\section{Pembahasan}

\section{Implementasi Reformasi Birokrasi Perizinan Penanaman Modal di Kabupaten}

\section{Kuningan.}

Kabupaten Kuningan merupakan daerah pertanian berlokasi di kaki Gunung Ciremai dan memiliki sumber air melimpah, termasuk air tawar 620 mata air dan 43 sungai kecil dengan debit air total 8.352 liter / detik, dan karena itu penuh potensial agribisnis dan investasi dalam air berbasis perusahaan. Kabupaten Kuningan yang strategis dan berlokasi dekat dengan Pelabuhan Cirebon yang melayani jalur utama

\footnotetext{
${ }^{15}$ Tim penyusun Ombudsprudensi Indonesia, Ombudsprudensi, (Jakarta : Ombudsman Republik Indonesia, 2009),hlm.29.
} 
pelayaran di Laut Jawa .. Investasi di Kuningan memiliki prospek cerah dalam memenuhi tuntutan pasar wilayah DKI Barat, Jawa Tengah dan daerah Pesisir Utara Jawa sehingga kegiatan ekonominya berdasarkan potensi agribisnis ynag berhubungan dengan sumber daya alamnya. Kabupaten Kuningan, adalah sebuah kabupaten di Provinsi Jawa Barat, Indonesia. Ibukotanya adalah Kuningan. Letak astronomis kabupaten ini di antara 108 $23^{\circ}$ - 108 $47^{\circ}$ Bujur Timur dan 6 $6^{\circ} 45^{\prime \prime}-7^{\circ} 13^{\prime \prime}$ Lintang Selatan. Kabupaten ini terletak di bagian timur Jawa Barat, berbatasan dengan Kabupaten Cirebon di utara, Kabupaten Brebes (Jawa Tengah) di timur, Kabupaten Ciamis di selatan, serta Kabupaten Majalengka di barat. Kabupaten Kuningan terdiri atas 32 kecamatan, yang dibagi lagi atas sejumlah 361 desa dan 15 kelurahan. Pusat pemerintahan di Kecamatan Kuningan. Badan Pelayanan Perizinan Terpadu Kabupaten Kuningan dibentuk untuk memenuhi kebutuhan masyarakat akan pelayanan publik yang cepat, efisien dan terjangkau, mempunyai dasar hukum yaitu

a. UndangUndangNomor 32 Tahun 2004 tentang Pemerintah Daerah telah diubah menjadi Undang - Undang Nomor 8 Tahun 2005 tentang Penetapan Peraturan Pemerintah Pengganti Undang-Undang Nomor 3 Tahun 2005 tentang Pemerintah Daerah menjadi UndangUndang.

b. Undang-Undang Nomor 25 Tahun 2007 tentang Penanaman Modal.

c. Peraturan Pemerintah Nomor 38 Tahun 2007 Antara Pemerintah, Pemerintahan Daerah Provinsi, dan Pemerintahan Daerah Kabupaten/Kota.

d. Peraturan Pemerintahan Nomor 41 Tahun 2007 tentang Organisasi Perangkat Daerah.

e. Instruksi Presiden Nomor 3 Tahun 2006 tentang Paket Kebijakan Perbaikan Iklim Investasi.

f. Peraturan Menteri Dalam Negeri Nomor 24 Tahun 2006 tentang Pedoman Penyelenggaraan Pelayanan Satu Pintu.

g. Peraturan Daerah Kabupaten Kuningan Nomor 21 Tahun 2006 tentang Pembentukan Badan Perizinan Terpadu.

Badan Pelayanan Perizinan Terpadu kabupaten Kuningan mempunyai Visi yaitu Terwujudnya pelayanan perizinan dan fasilitasi penanaman modal daerah yang 
prima sesuai dengan keinginan dan harapan konsumen dan mempunayai Misi antara lain :

1. Meningkatkan standar dan mutu pelayanan perizinan dan fasilitasi penanaman modal dalam upaya mendorong dan menumbuh kembangkan kegiatan masyarakat yang efektif, efesien dan berdaya saing dalam menghadapi tantangan masa depan

2. Meningkatkan kesadarn dan ketaatan masyarakat untuk memiliki perizinan sesuai dengan peraturan dan perundang-undangan yang berlaku

3. Menciptakan tertib administrasi dan tertib pembangunan yang dilaksanakan oleh masyarakat dan pemerintah sebagai acuan dasar dalam pengambilan kebijakan pembangunan

4. Meningkatkan penanaman modal daerah dalam mendorong pertumbuhan ekonomi dan pendapatan masyarakat untuk mewujudkan peningkatan pembangunan daerah

5. Melakukan penelitian dan pengkajian potensi peluang investasi daerah secara berkelanjutan guna mewujudkan kerjasama dengan investor dan membuka peluang bagi semua pihak dengan memperhatikan potensi perkembangan perekonomian rakyat

Badan Pelayanan Perizinan Terpadu kabupaten Kuningan di bentuk oleh pemerintahan Kabupaten Kuningan mempunyai tujuan yaitu antara lain yaitu :

1. Meningkatkan kualitas pelayanan perizinan

2. Meningkatkan kualitas perencanaan dan evaluasi kinerja pelayanan perizinan

3. Pemberian kemudahan informasi dan layanan kepada masyarakat

4. Meningkatkan daya dukung sektor perizinan dan fasilitas penanaman modal terhadap pemberdayaan dan pertumbuhan ekonomi masyarakat dalam pembangunan daerah

5. Meningkatkan konstribusi dari sektor perizinan terhadap Pendapatan Asli Daerah (PAD)

Berdasarkan Peraturan Daerah Kabupaten Kuningan Nomor 21 Tahun 2006 tentang Pembentukan Badan Perizinan Terpadu Kabupaten Kuningan maka Badan 
Pelayanan Perizinan Terpadu Kabupaten Kuningan mempunyai struktur organisasi yang berfungsi untuk mempermudah dalam pelayanan terhadap masyarakat yaitu terdiri dari :

Kepala Badan

1. Sekretariat
a. Sub Bagian Umum
b. Sub Bagian Keuangan

2. Bidang Pengembangan Data dan Informasi
a. Sub Bidang Program
b. Sub Bidang Data dan Informasi

3. Bidang Penanaman Modal
a. Sub Bidang Promosi dan Pengembangan
b. Sub Bidang Fasilitasi Penanaman Modal

4. Bidang Pelayanan
a. Sub Bidang Validasi
b. Sub Bidang Legislasi

5. Kelompok Jabatan Fungsional

Badan Pelayanan Perizinan Terpadu Kabupaten Kuningan dibentuk berdasarkan Peraturan Daerah Kabupaten Kuningan Nomor 27 Tahun 2006 tentang Pembentukan, Susunan Organisasi dan Tata Kerja Kantor Pelayanan Terpadu Satu Pintu Kabupaten Kuningan, dengan Tugas dan Fungsinya adalah melaksanakan kewenangan Pemerintahan di bidang Pelayanan Terpadu Satu Pintu (PTSP) Salah satu kewenangan yang diberikan adalah Pengelolaan dan Penandatanganan Perizinan berdasarkan Peraturan Bupati Nomor 13 Tahun 2009. Pelimpahan Sebahagian Kewenangan Pengelolaan dibidang Perizinan dan Non Perizinan dimaksud meliputi penerbitan izin, duplikat izin, legalisir izin, penarikan pajak reklame dan Retribusi, dan penandatanganan izin atas nama Bupati Kuningan. 
Sesuai dengan Peraturan Bupati Nomor 13 Tahun 2009 Izin-izin yang dikelola dan dilayani oleh Kepala Badan Pelayanan Terpadu Satu Pintu Kabupaten Kuningan adalah 30 jenis sebagai berikut :

1) Surat Izin Usaha industri (SIUI),

2) Surat Izin Usaha Perdagangan (SIUP),

3) Izin Mendirikan Bangunan (IMB),

4) Izin Lokasi,

5) Izin Gangguan (HO),

6) Surat Izin Tempat Usaha (SITU),

7) Izin Usaha Pariwisata,

8) Tanda Daftar Perusahaan (TDP),

9) Tanda Daftar Gudang (TDG),

10) Izin Lembaga Latihan Swasta,

11) Izin Penyelenggaraan Reklame,

12) Izin Usaha Angkutan (SIUA),

13) Izin Usaha Bengkel (SUIB),

14) Izin penyelenggaraan Parkir,

15) Izin Penghunian Kios dan Los,

16) Surat Keterangan Pedagang

17) Penanaman Modal,

18) Izin Usaha Peternakan,

19) Izin Pemotongan Hewan,

20) Izin Aneka Usaha Hasil Hutan,

21) SIP Bidan Perorangan,

22) Izin Balai Pengobatan,

23) Izin Apotek,

24) Toko Obat Berizin (TOB),

25) Optikal,

26) Izin Salon Kecantikan,

27) Izin Lembaga Kursus dan pelatihan, 
28) Izin Operasional Pendirian TK/SD/SMA/PT SWASTA

29) Pengesahan Rencana Pengunaan Ruang,

30) Izin Usaha Jasa Konstruksi,

\section{Manfaat Reformasi Birokrasi di Sektor Perizinan Penanaman Modal Bagi Masyarakat.}

Berdasarkan tujuan dari reformasi birokrasi adalah untuk membangun pemerintahan yang bersih, meningkatkan pelayanan publik, dan tersimpul dalam penyelenggaraan negara yang baik. Berdasarkan Presiden Nomor 03 Tahun 2006 tentang Paket Kebijakan Perbaikan Iklim Investasi. Dan ditindak lanjuti oleh Peraturan Menteri Dalam Negeri Nomor 24 Tahun 2006 tentang Pedoman Penyelenggaraan Pelayanan Satu Pintu dan Peraturan Gubernur Jawa Barat Nomor. 29 tahun tentang Perubahan Peraturan Penyelenggaraan Pelayanan Terpadu Satu Pintu maka daerah membentuk badan perizinan yang bersifat terpadu dan terpublikasi baik melalui papan pengumuman, brosur-brosur, pusat informasi dan website lembaga mengenai prosedur, persyaratan, waktu dan biaya yang di butuhkan dalam proses perizinan sehingga lembaga yang berfungsi untuk melayani proses perizinan khususnya berkaitan dengan perizinan penanaman modal. Salah satu ciri Negara maju adalah diterapkannya konsep dan prinsip-prinsip tata kelola pemerintahan yang baik dalam pelayanan publik, baik yang bersifat profit misalnya PDAM, listeik, telepon, transportasi, maupun yang non profit semacam STNK, SIM, KTP dan Paspor. Kedua jenis pelayanan publik ini seharusnya memperhatikan prinsip-prinsip dasar pelayanan public yang baik yaitu adanya keterbukaan dalam hal informasi, kepastian waktu dan harga, serta kerterjangkauannya. Selain itu juga harus diperhatikan faktor keadilan yaitu tidak diskriminatif. Kondisi pelayanan publik akan buruk apabila tidak adanya kesadaran masyarakat sendiri dan tidak adanya akses masyarakat untuk menyampaikan permasalahan- permaslahan yang ada(Zoemrotin K. Soesilo : 2001,99). Sebelum adanya reformasi birokrasi perizinan dilakukan oleh beberapa dinas teknis di daerah seperti dinas perindustrian dan perdaganagan mengeluarkan perizinan yang berkaitan dengan perizinan perdagaangan dan perindustrian yaitu surat 
izin usaha perdagangan (SIUP), surat izin usaha industri (SIUI), tanda Daftar Perusahaan (TDP), Tanda Daftar Gudang (TDG). Dinas bina marga yang megeluarkan perizinan yang berkaitan dengan masalah pembangunan proyek rumah, jalan dan jembatan yaitu Surat Izin Usaha Jasa Konstruksi (SIUJK). Izin Mendirikan Bangunan (IMB) instansi yang mengeluarkan adalah Dinas Tata Ruang dan Bangunan Kabupaten atau Kota. Surat Izin Usaha Pariwisata (SIUP) instansi yang mengeluarkan adalah Dinas Kebudayaan dan Pariwisata Kabupaten dan Kota. Berdasarkan Peraturan Menteri dalam Negeri Nomor 20 Tahun 2008 tentang Pedoman Organisasi dan Tata Kerja Unit Pelayanan Terpadu maka dibentuklah badan tersendiri yaitu badan pelayanan perizinan terpadu yang mengeluarkan berbagai perizinan yang tadinya dikeluarkan oleh dinas-dinas secara terpisah maka dengan adanya badan sendiri yang bertugas mengeluarkan masalah perizinan. Dengan adanya badan pelayanan perizinan terpadu maka para pemohon perizinan cukup datang ke satu tempat maka semua perizinan dapat dimohonkan sehingga menghemat waktu dan kepastian biaya. Reformasi birokrasi mempunyai manfaat dalam proses pelayanan yang berorientasi pada kepuasan publik dan ketaatan aparatur birokasi terhadap peraturan perundang-undangan sehingga tidak terjadi penyimpangan dan perbuatan tercela.

\section{Penutup}

\section{Simpulan}

Berdasarkan Peraturan Daerah Kabupaten Kuningan Nomor 21 Tahun 2006 tentang Pembentukan Badan Perizinan Terpadu Kabupaten Kuningan maka Badan Pelayanan Perizinan Terpadu Kabupaten Kuningan mempunyai struktur organisasi yang berfungsi untuk mempermudah dalam pelayanan terhadap masyarakat dan Sesuai dengan Peraturan Bupati Nomor 13 Tahun 2009 Izin-izin yang dikelola dan dilayani oleh Kepala Badan Pelayanan Terpadu Satu Pintu Kabupaten Kuningan adalah 30 jenis perizinan dan Sebelum adanya reformasi birokrasi perizinan dilakukan oleh beberapa dinas teknis di daerah seperti Dinas Perindustrian dan Perdaganagan mengeluarkan perizinan yang berkaitan dengan perizinan perdagaangan dan 
perindustrian yaitu surat izin usaha perdagangan (SIUP), surat izin usaha industri (SIUI), tanda Daftar Perusahaan (TDP), Tanda Daftar Gudang (TDG).

\section{Saran}

Melakukan dan memaksimalakan sosialisasi tentang adanya lembaga perizinan terpadu satu atap di kota atau kabupaten setempat, sehingga masyarakat pada umumnya dan pengausaha khususnya mengetahui mengenai prosedur, persyaratan, biaya dan waktu yang di butuhan dalam proses mendapatkan suatu perizinan. Meningkatkan sarana pra-sarana yaitu berupa kendaraan operasional untuk melakukan kegiatan survey, dan lain-lain sehingga meningkatkan waktu proses pelayanan menjadi lebih cepat serta menambah lahan parkir dan gudang arsip sehingga menambah daya tampung, sehingga dalam melakukan proses permohonan perizianan menjadi lebih yaman dan aman.

\section{DAFTAR PUSTAKA}

Delfitri, Yefni, 2006, Reformasi Birokrasi di Mahkama Agung, Jakarta: Tesis Universitas Krisnadwipayana,

Fajar Sidiq, Fathir, Kasus Gizi Buruk dan Wajah Pelayanan Publik di Kota Depok”, www.radardepok.com, , Diakses tanggal 24 Desember 2012

Kaligis, O.C, 2007, Dasar Hukum Mengadili Kebijakan Publik, Jakarta : PT. Alumni. Rahardjo, Sajipto, 1982, Ilmu Hukum, cet.2006, Bandung : PT.Citra Aditya Bhakti. Saleh, Asri M, “Arti Penting Kehadiran Ombudsman Bagi Masyarakat Di Provinsi Riau”, Jurnal Hukum Respublica. Vol.3 No.2 Tahun 2004. Pekanbaru: FH Universitas Lancang Kuning.

Soekanto, Soerjono, 1984, Pengantar Penelitian Hukum.cet.2007, Jakarta : UI Press. ,(1990), Ringkasan metode Penelitian Hukum Empiris cet.2006,

Jakarta:Ind-Hill.

Soeprapto, Riyadi, Pengembangan Model Citizen Charter Dalam Meningkatkan Pelayanan Publik Di Indonesia, Jurnal Delegasi, No. 2 Agustus 2005 
Tim Penyusun Ombudsprudensi Indonesia, 2009, Ombudsprudensi, Jakarta :

Ombudsman Republik Indonesia.

Tjokroamidjoyo, Bintoro, 2001, Reformasi Administrasi Publik, Jakarta: MIA-Unkris Press.

www.transparansi.or.id, Tata Kelola Pemerintahan Yang Baik, Diakses tanggal 04

Desember 2012

www.beritakota.com,“Wajah Birokrasi Kita”,.Diakses tanggal 30 Desember 2012.

Yogi S dan Ikhsan, 2006 , Standar Pelayanan Publik Di Daerah, Jakarta : Hand Book Manajemen Pemerintahan Daerah, LAN.

Undang-Undang Nomor 25 Tahun 2007 tentang Penanaman Modal

Undang-Undang Nomor 25 Tahun 2009 tentang Pelayanan Publik

Peraturan Menteri Dalam Negeri Nomor 24 Tahun 2006 tentang Pedoman Penyelenggaraan Pelayanan Terpadu Satu Atap.

Peraturan Menteri dalam Negeri Nomor 20 Tahun 2008 tentang Pedoman Organisasi dan Tata Kerja Unit Pelayanan Terpadu

Peraturan Daerah Kabupaten Kuningan Nomor 21 Tahun 2006 tentang Pembentukan Badan Perizinan Terpadu. 